\title{
Megacities and tall buildings: symbiosis
}

\author{
Daniel Safarik ${ }^{1 *}$, Shawn $\mathrm{Ursini}^{l}$ and Antony Wood ${ }^{l}$ \\ ${ }^{1}$ Council on Tall Buildings and Urban Habitat, 104 South Michigan Ave., Suite 620, Chicago, IL, \\ 60603, United States
}

\begin{abstract}
Anyone concerned with the development of human civilization in the 21st Century will likely have heard the term «megacity». It is - as it should be - increasingly prevalent in both mainstream and academic discussions of the great trends of our time: urbanization, rising technological and physical connectivity, increasingly polarized extremes of wealth and poverty, environmental degradation, and climate change. It is a subject as large and far-reaching as its name implies. This paper sets the scene on how megacities and the built environment are growing together, and examines the implications for those who plan, design, develop and operate tall buildings and urban infrastructure.
\end{abstract}

\section{What is a Megacity?}

In order to rationalize the data CTBUH collects - predominantly on skyscrapers and large urban developments - with that collected by other organizations, first a definition that reflects a distillation of the prominent literature on the subject should be set forth:

A megacity is an urban agglomeration with a total population of 10 million people or greater, consisting of a continuous built-up area that encompasses one or more city centers and suburban areas, economically and functionally linked to those centers.

A megacity is typically, though not always, polycentric, with multiple nodes of concentrated urban activity and high-density development, rather than being centered around one large primary central business district (CBD). Indeed, a telltale sign of a megacity, and an indicator of its polycentric nature, is the tendency of residents and urban planners alike to refer to more than one «CBD». Even if there is a consensus about the location of the «center of town», development and transportation patterns strongly suggest otherwise; it should be thought of as an interwoven web, rather than a series of concentric zones.

The polycentric pattern is often the result of established urban centers traditionally separated by distance and their own identities eventually merging together through a continuous spread of urban and suburban development. A key aspect of the megacity is that these linkages of urbanity fuse the agglomeration together, not only physically, but also economically, functionally, and often, culturally.

In a megacity, the extent of urban development spread will not be described by a single radius or a compact, circular shape; in other words, it is asymmetrical and polymorphic.

\footnotetext{
*Corresponding author: dsafarik@ctbuh.org
} 
This is due to a variety of factors, including but not limited to; uneven development patterns, geographic obstacles, transport corridors and political boundaries. While green spaces and «undeveloped» land may separate urban centers, this does not necessarily indicate that there is a definitive economic, cultural or political division between cities and their relationship within a megacity.

In other words, there may be considerable amounts of open space contained within a megacity (see Fig. 1).

Open spaces could be the result of geological features such as mountains and bodies of water, military installations or protected greenbelts. Meanwhile, «leapfrog» development has a tendency to create long, narrow strands of development along transportation routes, which then fill in perpendicularly to those corridors over time.

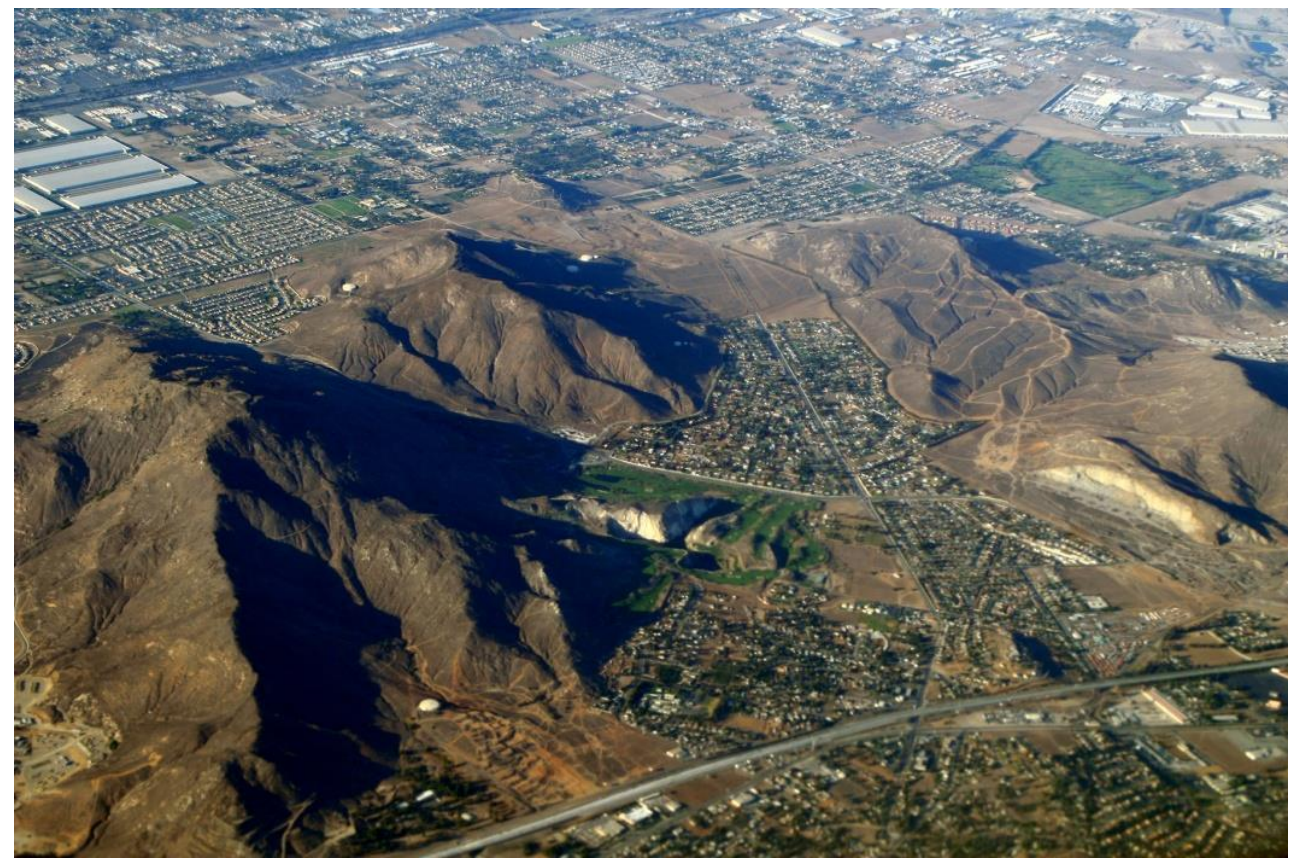

Fig. 1. Example of an undeveloped space comprised of mountains and farms within an urbanized area, in this case, Los Angeles. (Source: CC BY-SA Doc Searls).

For the purposes of the 45 megacities noted in this study (see Table 1), it should be clearly noted that the cited population, area and density figures are the result of existing political boundaries which can dilute density numbers, because they may encompass open spaces and adjacent hinterlands potentially available for future development lying beyond highly built-up areas.

For example, if a district, county, prefecture or other political jurisdiction adjoins a heavily built-up area, and a distinctly dense tendril of urban land penetrates into what is otherwise a rural political unit, along a watercourse, highway or railway, the entire surrounding political unit is typically counted in area and population figures.

Thus, the «Los Angeles» megacity in this study extends all the way through open desert to the Colorado River and the border with Arizona, because the political entity of Riverside County, California - heavily urbanized in the west and sparsely populated in the east - is included. 
Table 1. List of 45 megacities ranked by population. (Source: See «Population and Area Sources» in References)

\begin{tabular}{|c|c|c|c|c|c|c|c|}
\hline 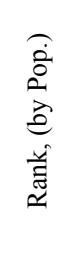 & Megacity & $\stackrel{\gtrsim}{\Xi}$ & 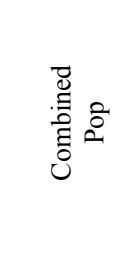 & 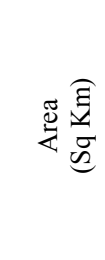 & 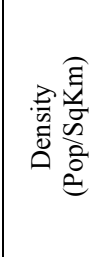 & 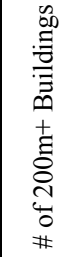 & Cities \& Administrative areas within \\
\hline 1 & $\begin{array}{l}\text { Pearl River } \\
\text { Delta }\end{array}$ & China & $64,899,778$ & 56,217 & 1,154 & 220 & $\begin{array}{l}\text { Guangzhou, Shenzhen, Hong Kong, } \\
\text { Foshan, Dongguan, Huizhou, } \\
\text { Zhaoqing, Zhongshan, Zuhai, } \\
\text { Jiangmen, Macau }\end{array}$ \\
\hline 2 & \begin{tabular}{|l|} 
Shanghai- \\
Changzhou
\end{tabular} & China & $50,302,212$ & 28,010 & 1,796 & 90 & $\begin{array}{l}\text { Shanghai, Suzhou, Wuxi, } \\
\text { Changzhou, Jiaxing }\end{array}$ \\
\hline 3 & \begin{tabular}{|l|} 
Tokyo \\
(Kanto \\
Region)
\end{tabular} & Japan & $42,797,000$ & 32,424 & 1,320 & 29 & $\begin{array}{l}\text { Prefectures of Tokyo, Kanagawa, } \\
\text { Saitama, Gunma, Tochigi, Ibaraki \& } \\
\text { Chiba }\end{array}$ \\
\hline 4 & \begin{tabular}{|l} 
Beijing- \\
Tianjin \\
\end{tabular} & China & $40,594,839$ & 34,588 & 1,174 & 50 & Beijing, Tianjin, Langfang \\
\hline 5 & Delhi & India & $34,397,873$ & 15,562 & 2,210 & 3 & $\begin{array}{l}\text { Delhi, Nodia, Gurgaon, Ghaziabad, } \\
\text { Rohtak, Meerut }\end{array}$ \\
\hline 6 & $\begin{array}{l}\text { New York- } \\
\text { Philadelphia }\end{array}$ & USA & $30,907,175$ & 54,880 & 563 & 96 & $\begin{array}{l}\text { New York, New Haven, Jersey City, } \\
\text { Philadelphia, Wilmington, Trenton, } \\
\text { Atlantic City }\end{array}$ \\
\hline 7 & Chongqing & China & $30,165,500$ & 82,403 & 366 & 46 & Chongqing Province \\
\hline 8 & Sao Paulo & Brazil & $29,740,692$ & 23,556 & 1,263 & 0 & $\begin{array}{l}\text { Sao Paulo, Campinas, Baixada } \\
\text { Santista, Santos, Sorocaba, Sao Jose } \\
\text { dos Campos }\end{array}$ \\
\hline 9 & Jakarta & Indonesia & $28,424,717$ & 6,438 & 4,415 & 46 & $\begin{array}{l}\text { Jakarta, Depak, Bogor, Tangerang, } \\
\text { Bekasi }\end{array}$ \\
\hline 10 & Mumbai & India & $26,136,721$ & 17,313 & 1,510 & 38 & $\begin{array}{l}\text { Districts of Mumbai, Mumbai } \\
\text { Suburban, Thane, Pulghar \& Raigad }\end{array}$ \\
\hline 11 & $\begin{array}{l}\text { Seoul- } \\
\text { Incheon }\end{array}$ & \begin{tabular}{|l|} 
South \\
Korea \\
\end{tabular} & $25,524,572$ & 11,807 & 2,162 & 39 & Seoul, Incheon, Gyeonggi Province \\
\hline 12 & Manila & Philippines & $25,169,197$ & 8,113 & 3,102 & 30 & $\begin{array}{l}\text { National Capitol Region and } \\
\text { Provinces of Rizal, Leguna, Cavite, } \\
\text { Bulacan }\end{array}$ \\
\hline 13 & Dhaka & $\begin{array}{l}\text { Banglades } \\
\mathrm{h}\end{array}$ & $24,952,038$ & 9,353 & 2,668 & 0 & $\begin{array}{l}\text { Districts of Dhaka, Narayanganj, } \\
\text { Mymensingh, Munshiganj \& Gazipur } \\
\text { within Dhaka Division. }\end{array}$ \\
\hline 14 & Karachi & Pakistan & $23,500,000$ & 3,527 & 6,663 & 1 & Karachi Administrative District \\
\hline 15 & Mexico City & Mexico & $23,492,352$ & 11,317 & 2,076 & 6 & $\begin{array}{l}\text { Metropolitain areas of Mexico City, } \\
\text { Toluca, Tianguistenco, Tula and the } \\
\text { municipality of Tepeji del Río de } \\
\text { Ocampo }\end{array}$ \\
\hline 16 & Cairo & Egypt & $21,455,656$ & 6,649 & 3,227 & 0 & $\begin{array}{l}\text { Cairo, Al Qalyubia \& Giza } \\
\text { Governorate }\end{array}$ \\
\hline 17 & $\begin{array}{l}\text { Hangzhou- } \\
\text { Ningbo }\end{array}$ & China & $21,218,301$ & 34,936 & 607 & 24 & $\begin{array}{l}\text { Hangzhou, Shaoxing, } \\
\text { Ningbo }\end{array}$ \\
\hline 18 & Osaka & Japan & $20,750,000$ & 27,351 & 759 & 6 & $\begin{array}{l}\text { Prefectures of Osaka, Shiga, Nara, } \\
\text { Kyoto, Wakayama \& Hyogo; } \\
\text { including the cities of Kobe, Hemeji } \\
\text { and Izumisano }\end{array}$ \\
\hline 19 & Kolkata & India & $20,608,327$ & 18,885 & 1,091 & 1 & $\begin{array}{l}\text { Districts of Kolkata, Howrah, } \\
\text { Hooghly, North } 24 \text { Parganas, South } \\
24 \text { Parganas }\end{array}$ \\
\hline 20 & Lahore & Pakistan & $20,530,000$ & 12,631 & 1,625 & 0 & $\begin{array}{l}\text { Districts of Lahore, Sheikhupura, } \\
\text { Gujranwala, Kasur }\end{array}$ \\
\hline
\end{tabular}




\begin{tabular}{|c|c|c|c|c|c|c|c|}
\hline 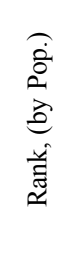 & Megacity & 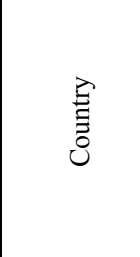 & 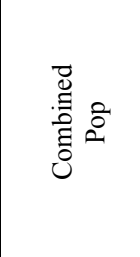 & 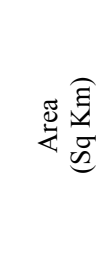 & 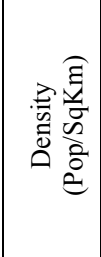 & 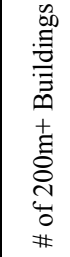 & Cities \& Administrative areas within \\
\hline 21 & Moscow & Russia & $19,002,220$ & 33,262 & 571 & 19 & $\begin{array}{l}\text { Moscow City and the more urbanized } \\
\text { portions of the Moscow Oblast }\end{array}$ \\
\hline 22 & Los Angeles & USA & $18,679,763$ & 87,944 & 212 & 13 & $\begin{array}{l}\text { Los Angeles, Long Beach, Riverside, } \\
\text { Oxnard }\end{array}$ \\
\hline 23 & Ho Chi Minh & Vietnam & $18,051,200$ & 23,724 & 761 & 7 & $\begin{array}{l}\text { Ho Chi Minh City \& Provinces of Ba } \\
\text { Ria-Vung Tau, Dong Nai, Tien } \\
\text { Giang, Long An, Binh Duong, Tay } \\
\text { Ninh }\end{array}$ \\
\hline 24 & Bangkok & Thailand & $17,718,258$ & 21,028 & 843 & 20 & $\begin{array}{l}\text { Provinces of Bangkok, Chon Buri, } \\
\text { Nakhon Patham, Pathum Thani, } \\
\text { Samut Sakhon, Samout Prakan, } \\
\text { Nonthaburi, Chachoengsao, Rayong }\end{array}$ \\
\hline 25 & Chengdu & China & $17,663,383$ & 18,115 & 975 & 24 & Chengdu, Deyang \\
\hline 26 & Xiamen & China & $16,469,863$ & 25,792 & 639 & 20 & Xiamen, Zhangzhou, Quanzhou \\
\hline 27 & Istanbul & Turkey & $16,437,489$ & 8,808 & 1,866 & 7 & $\begin{array}{l}\text { Istanbul and Kocaeli provinces, } \\
\text { including the districts of Izmit and } \\
\text { Gebze }\end{array}$ \\
\hline 28 & Tehran & Iran & $15,450,000$ & 18,814 & 821 & 0 & $\begin{array}{l}\text { Provinces of Tehran and Alborz, } \\
\text { including the cities of Karaj, } \\
\text { Varamin and Eslamshahr }\end{array}$ \\
\hline 29 & Buenos Aires & Argentina & $15,333,035$ & 11,134 & 1,377 & 1 & $\begin{array}{l}\text { Greater Buenos Aires and La Plata } \\
\text { Metropolitan Areas }\end{array}$ \\
\hline 30 & London & \begin{tabular}{|l|} 
United \\
Kingdom \\
\end{tabular} & $14,031,830$ & 12,091 & 1,161 & 8 & $\begin{array}{l}\text { London and the districts of Surrey, } \\
\text { Kent, Essex, Hertfordshire }\end{array}$ \\
\hline 31 & Shantou & China & $13,943,141$ & 10,660 & 1,308 & 0 & Shantou, Jieyang, Chaozhou \\
\hline 32 & $\begin{array}{l}\text { Johannesbur } \\
\text { g-Pretoria }\end{array}$ & $\begin{array}{l}\text { South } \\
\text { Africa }\end{array}$ & $13,937,500$ & 22,017 & 633 & 1 & $\begin{array}{l}\text { Gautang Province (including } \\
\text { Johannesburg, Pretoria, Midrand) } \\
\text { and the municipality of Madibeng }\end{array}$ \\
\hline 33 & Bangalore & India & $13,093,168$ & 13,139 & 997 & 0 & $\begin{array}{l}\text { Bangalore, Ramanagara, Krishnagiri } \\
\text { Districts }\end{array}$ \\
\hline 34 & Kinshasa & $\begin{array}{l}\text { Democrati } \\
\text { c Republic } \\
\text { of Congo, } \\
\text { Republic } \\
\text { of the } \\
\text { Congo } \\
\end{array}$ & $13,271,392$ & 10,229 & 1,297 & 0 & Kinshasa, Brazzaville \\
\hline 35 & Rhine-Ruhr & Germany & $12,695,656$ & 14,160 & 1,154 & 0 & $\begin{array}{l}\text { Bonn, Colonge, Dusseldorf, } \\
\text { Duisburg, Essen, Wuppertal, } \\
\text { Mönchengladbach }\end{array}$ \\
\hline 36 & $\begin{array}{l}\text { Chicago- } \\
\text { Milwaukee }\end{array}$ & $\begin{array}{l}\text { United } \\
\text { States of } \\
\text { America }\end{array}$ & $11,970,050$ & 37,324 & 321 & 31 & $\begin{array}{l}\text { Chicago, Milwuakee, Naperville, } \\
\text { Michigan City, Shaumburg, } \\
\text { Kankakee }\end{array}$ \\
\hline 37 & Lagos & Nigeria & $12,864,745$ & 20,107 & 640 & 0 & Lagos State, Ogun State \\
\hline 38 & $\begin{array}{l}\text { Rio de } \\
\text { Janeiro }\end{array}$ & Brazil & $12,678,779$ & 7,249 & 1,749 & 0 & $\begin{array}{l}\text { Rio de Janeiro, San Goncalo, Dudue } \\
\text { de Caxias, Nova Iguacu, Belford } \\
\text { Roxo }\end{array}$ \\
\hline 39 & Chennai & India & $12,373,088$ & 8,052 & 1,537 & 0 & $\begin{array}{l}\text { Chennai, Thiruvallur, Kancheepuram } \\
\text { Districts }\end{array}$ \\
\hline 40 & Hyderabad & India & $12,273,352$ & 17409 & 705 & 0 & $\begin{array}{l}\text { Districts of Hyderabad, Rangareddy, } \\
\text { Medak }\end{array}$ \\
\hline 41 & Paris & France & $12,073,914$ & 12,011 & 1,005 & 2 & $\begin{array}{l}\text { Departments of Paris, Seine-et-, } \\
\text { Essonne, Seine-Saint-Denis Marne, }\end{array}$ \\
\hline
\end{tabular}




\begin{tabular}{|c|c|c|c|c|c|c|c|}
\hline 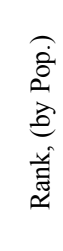 & Megacity & 兽 & 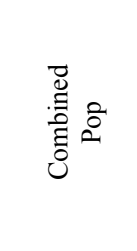 & 总言 & 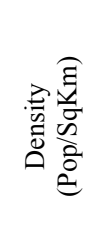 & 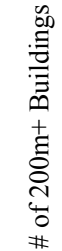 & Cities \& Administrative areas within \\
\hline & & & & & & & Yvelines, Val-de-Marne, Val-d'Oise \\
\hline 42 & Nagoya & Japan & $11,321,000$ & 21,567 & 525 & 4 & $\begin{array}{l}\text { Prefectures of Aichi, Gifu, Mie; } \\
\text { including the cities of Nagoya, Tsu } \\
\text { and Toyohashi }\end{array}$ \\
\hline 43 & Wuhan & China & $10,834,056$ & 10,088 & 1,074 & 29 & Wuhan, Ezhou \\
\hline 44 & Taipei & $\begin{array}{l}\text { Republic } \\
\text { of China } \\
\text { (Taiwan) }\end{array}$ & $10,280,569$ & 5,209 & 1,974 & 6 & $\begin{array}{l}\text { Taipei, New Taipei City, Keelung, } \\
\text { Taoyuan, Hsinchu }\end{array}$ \\
\hline \multirow[t]{4}{*}{45} & Shenyang & China & $10,244,261$ & 24,132 & 425 & 41 & Shenyang, Fushun \\
\hline & Totals: & & $\begin{array}{l}958,258,66 \\
2\end{array}$ & 990,025 & 968 & 958 & $\begin{array}{l}* 958=55.34 \% \text { of all } 200 \text { meter }+ \\
\text { buildings }\end{array}$ \\
\hline & & & & & & & $\begin{array}{l}\text { *958,258,662 = 13\% of global } \\
\text { population }\end{array}$ \\
\hline & & & & & & & $\begin{array}{l}* 990,025 \mathrm{sq} . \mathrm{km} .=0.66 \% \text { of global } \\
\text { land surface area }\end{array}$ \\
\hline
\end{tabular}

In step with the theme and site of the CTBUH 2016 Conference, the primary benchmark for a megacity in this study is the Pearl River Delta region of southern China, the world's largest megacity (see Fig. 2).
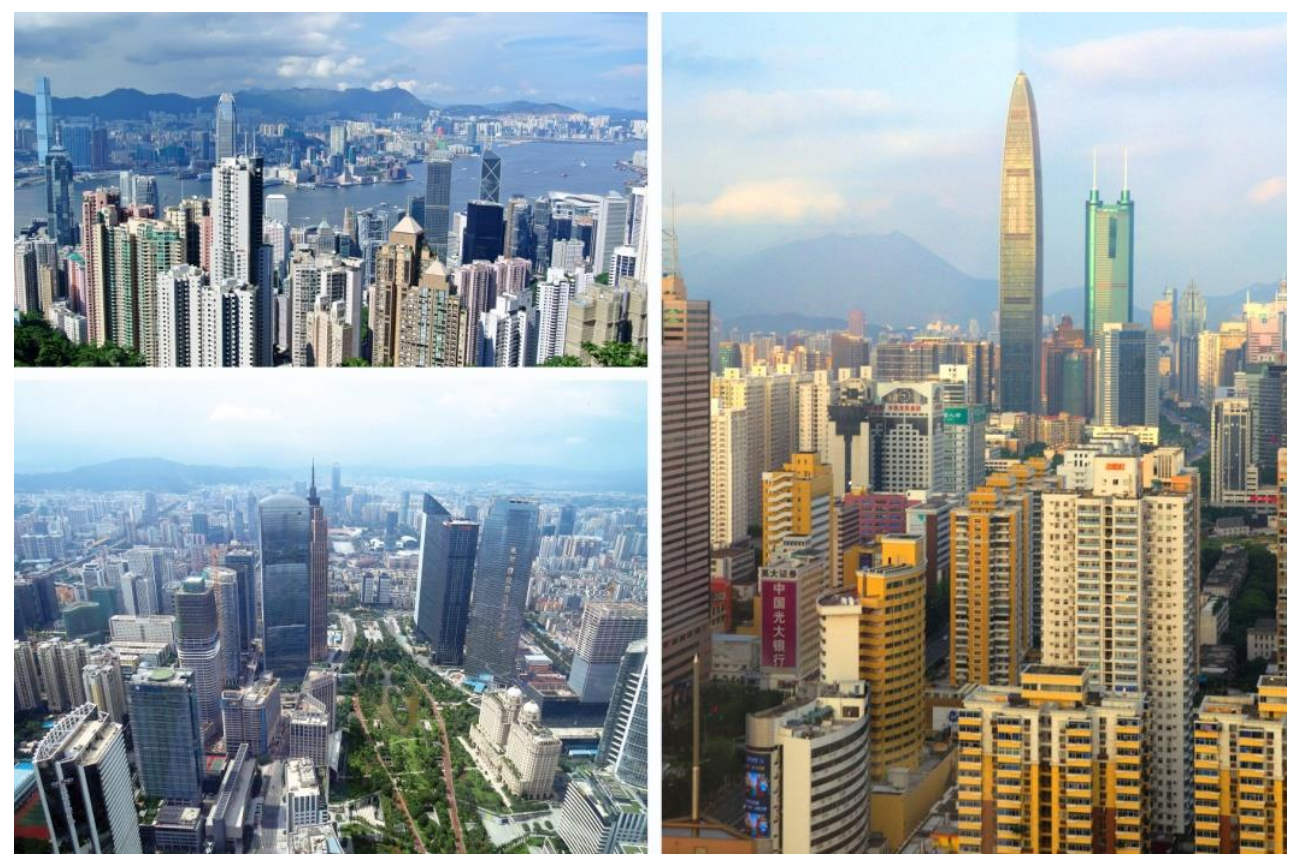

Fig. 2. The Pearl River Delta megacity boundaries (top) and the skylines of the three largest cities in it (left: Hong Kong and Guangzhou; right: Shenzhen). (Source: (top) Google Maps, citypopulation.de; (photos) James Antrobus, Tansri Muliani, and Popolon). 
Drawing a line around the boundaries of the Pearl River Delta's urban centers would encompass a span of up to $367 \mathrm{~km}$ from southwest to northeast (that is, from the southwestern-most corner of Jiangmen to the northeastern-most corner of Huizhou) and 331 $\mathrm{km}$ from northwest to southeast (that is, from the northwestern-most corner of Zhaoqing to the southeastern-most corner of Hong Kong). This boundary would give an area of 56,217 $\mathrm{km} 2$, which would actually rank it 127 th on the list of country areas around the world, just below Croatia, and above Costa Rica, Denmark, and Israel, for sheer size. It also would be the 12th largest country in terms of gross domestic product (GDP), lying between South Korea and Australia on the GDP per capita scale. Thus, as we can see, the Pearl River Delta megacity is comparable to numerous countries in terms of physical size, and far greater than many in terms of attributable economic output $[10,11,12]$. While many studies consider the Pearl River Delta and Hong Kong to be separate urban entities, due to Hong Kong's special administrative status within the People's Republic of China, this study includes Hong Kong, as all indicators point to the former British colony becoming more integrated with mainland China, and more to the point, with its immediate neighbors. The fact that it is currently a Special Administrative Region with a quasi-national boundary, a different political system, different currency - and, not insignificantly, left-hand driving acutely underscores one central quandary of the megacity: the economic and functional realities of these cities are often several steps ahead of their political realities $[8,9]$.

Estimates of the Pearl River Delta's population vary. The estimated current population for the Pearl River Delta, including Hong Kong, is 64.9 million. This would make it the 22nd-largest country in the world by population, just below the United Kingdom and just above France [1].

The Pearl River Delta encompasses an urbanized area spreading into a total of 11 different municipalities whose administrative divisions define the overall boundary of the megacity (see Fig. 2). Using this criterion, the second largest megacity would be ShanghaiChangzhou, which also includes the adjacent cities of Suzhou, Wuxi and Jiaxing for a total population of approximately 50.3 million. The third largest megacity is Tokyo, but under this study's parameters, «Tokyo» should be considered as the larger Kanto Region, which encompasses neighboring prefecture-level political divisions and balloons the population to about 42.8 million.

The methodology of this study attempts to normalize data collection across cities that vary greatly in terms of topography, organization and available information. As much previous study and literature has noted, it is unwise to assume that metropolitan planning models that work in one country, region, or even in a single city, will necessarily work in the next. The patterns of urbanization and densification are substantially different in different parts of the world. But as a means of identifying significant trends and issues, all megacities have something to teach each other, and our urbanizing world at large.

\section{Where are Megacities?}

Of the 45 megacities identified in this research, 29 (64\%) are in Asia, and 10 are in China alone $(22 \%)$. Another six are in India. Europe has five (11\%), North America and Africa have four ( $9 \%$ each), and South America has three (7\%) (see Fig. 3, 4).

There is no evidence that a megacity, purely based on size, is inherently ungovernable; for example, Tokyo is one of the best-run and most thoroughly-integrated urban areas anywhere, of any size $[2,7]$ - but it's also an outlier in almost every category. The much more typical scenario - found in a dozen or so megacities near the Equator- sees some of the bleakest poverty, deepest corruption, most daunting environmental circumstances, and most chaotic daily life on the planet. 


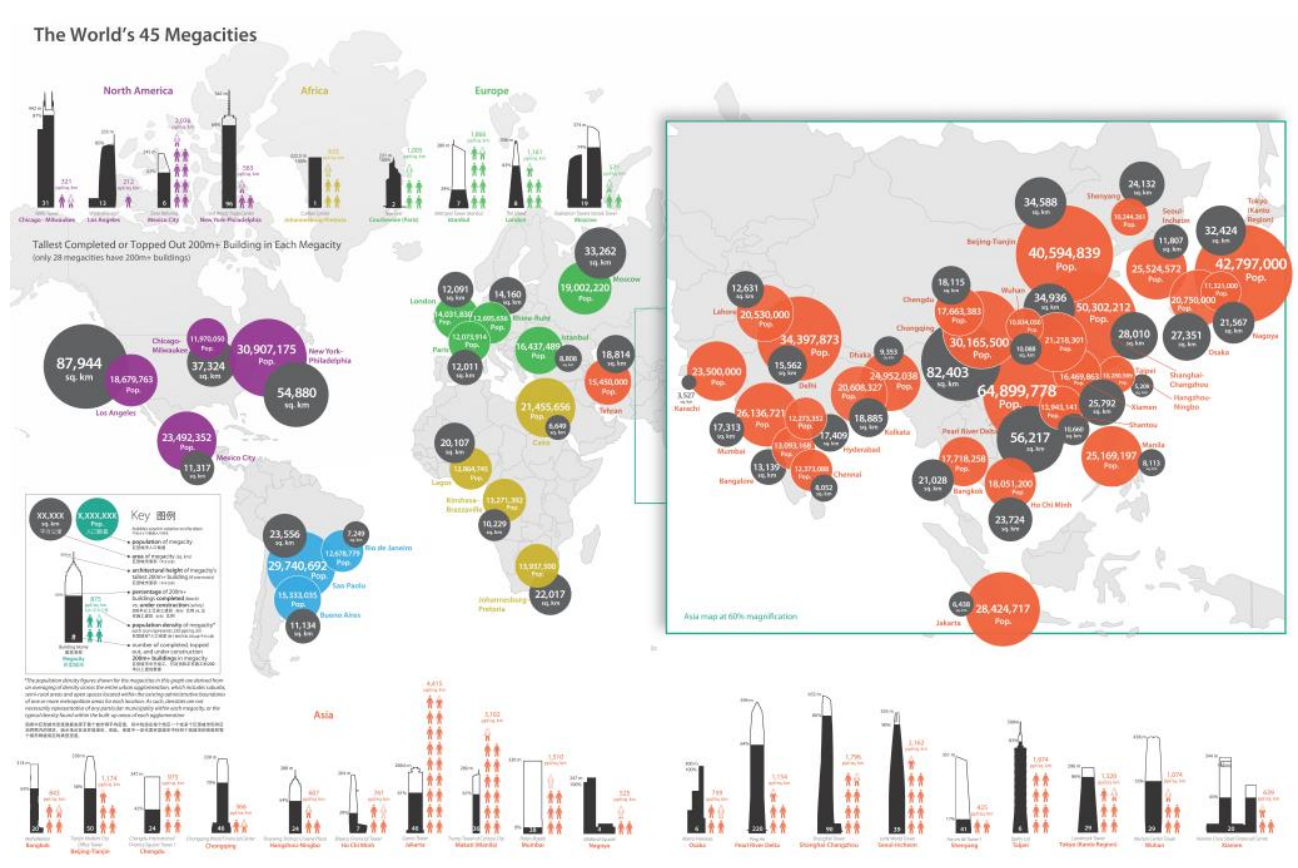

Fig. 3. Location, population, area, and population density of the world's 45 megacities. (Source: CTBUH Skyscraper Center and see «Population and Area Sources» in References).

Based on the United Nations Human Development Index (HDI) figures for 2015, 11 megacities are in the top quartile (or «Very High» HDI), including those in Germany, the United States and Japan; 18 are in second quartile or «High» category, including those in Russia, Brazil and China; 12 are in «developing» countries with «medium» HDI scores, including Indonesia, the Philippines, and India; and four are in «undeveloped» countries, including Pakistan, Nigeria, and the Democratic Republic of the Congo [3] (see Table 2).

Bearing in mind that 16 of the 45 megacities are in underdeveloped or developing countries, consider this: «Of the global urban population of 730 million in 1950, 300 million (42\%) lived in developing countries. By 2010, with a global urban population of 3.5 billion, 2.6 billion (73\%) lived in developing countries. In 2050, the figures will be 7.3 billion, 5.2 billion and $83 \%$, respectively. In other words, the urban population of developing countries will grow 15 times as much as in developed countries» [2].

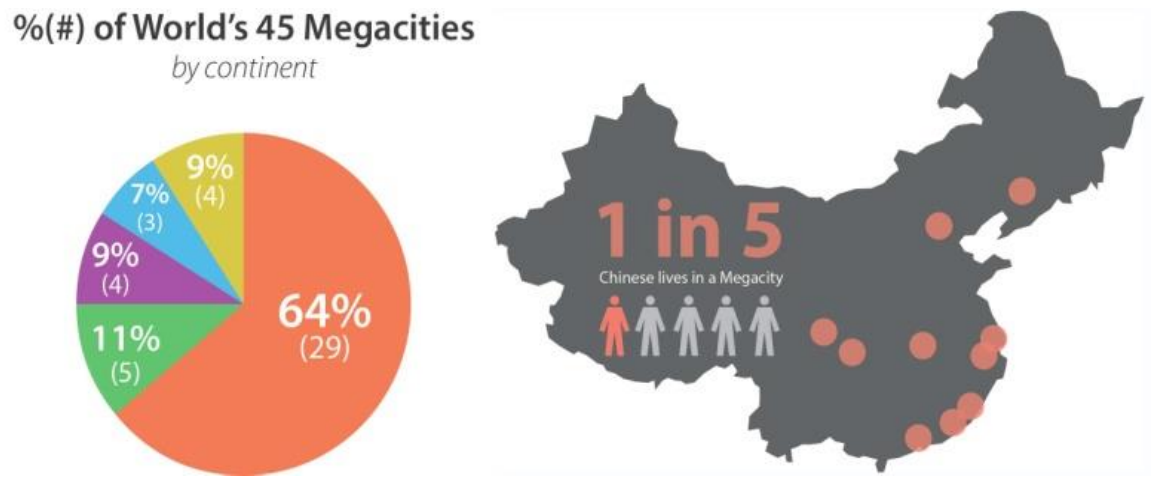

Fig. 4. Percentage and number of megacities in each continent and location of China's 10 megacities. Note: there are no megacities in the continents of Australia and Antarctica. (Source: CTBUH). 
In addition to the predominance of urban population growth in developing countries, a substantial portion of the largest megacities are doubly affected by their location. Put another way, the fastest-growing places are those in the most vulnerable positions geographically, with respect to natural disasters: «A ranking of world cities by size of population vulnerable to a range of natural disasters found that the six most vulnerable urban areas in the world were in East Asia» [4]. «Today, more than 1.5 billion of Asia's 4 billion people live within $100 \mathrm{~km}$ of the Indian or Pacific oceans, where rising sea levels could overwhelm existing coastal barriers. Mankind's voluntary concentration into a dense, coastal civilization is certainly efficient, but it may not be very wise» [5].

It is already well-acknowledged that coastal defenses must be a part of any long-range plan for most of the megacities of the world; the experience of New York City during Hurricane Sandy in 2012 - with billions of dollars of damage and disruption, and from which recovery continues to this day - underscored this. Practitioners in the tall-building community have already begun to respond to this issue.

Table 2. List of 45 megacities ranked by Country's Human Development Index (HDI). HDI is a composite statistic of life expectancy, education, and income per capita indicators, which are used to rank countries into four tiers of human development. A country scores higher HDI when the lifespan is higher, the education level is higher, the GDP per capita is higher, the fertility rate is lower, and the inflation rate is lower. (Source: World Bank 2, Wikipedia)

\begin{tabular}{|c|c|c|c|c|}
\hline HDI Rank & HDI Value & Quartile & Country & Megacities \\
\hline 5 & 0.916 & 1-Very High & Germany & Rhine-Ruhr \\
\hline 8 & 0.915 & 1-Very High & USA & New York-Philadelphia \\
\hline 8 & 0.915 & 1-Very High & USA & Los Angeles \\
\hline 8 & 0.915 & 1-Very High & USA & Chicago-Milwaukee \\
\hline 14 & 0.907 & 1-Very High & UK & London \\
\hline 17 & 0.898 & 1-Very High & South Korea & Seoul-Incheon \\
\hline 20 & 0.891 & 1-Very High & Japan & Tokyo (Kanto) \\
\hline 20 & 0.891 & 1-Very High & Japan & Osaka \\
\hline 20 & 0.891 & 1-Very High & Japan & Nagoya \\
\hline 22 & 0.888 & 1-Very High & France & Paris \\
\hline 40 & 0.836 & 1-Very High & Argentina & Buenos Aires \\
\hline 50 & 0.798 & 2-High & Russia & Moscow \\
\hline 69 & 0.766 & 2-High & Iran & Tehran \\
\hline 72 & 0.761 & 2-High & Turkey & Istanbul \\
\hline 74 & 0.756 & 2-High & Mexico & Mexico City \\
\hline 75 & 0.755 & 2-High & Brazil & Rio de Janeiro \\
\hline 75 & 0.755 & 2-High & Brazil & Sao Paulo \\
\hline 90 & 0.727 & 2-High & China & Pearl River Delta \\
\hline 90 & 0.727 & 2-High & China & Shanghai-Changzhou \\
\hline 90 & 0.727 & 2-High & China & Beijing-Tianjin \\
\hline 90 & 0.727 & 2-High & China & Chongqing \\
\hline 90 & 0.727 & 2-High & China & Hangzhou-Ningbo \\
\hline 90 & 0.727 & 2-High & China & Chengdu \\
\hline 90 & 0.727 & 2-High & China & Xiamen \\
\hline 90 & 0.727 & 2-High & China & Shantou \\
\hline 90 & 0.727 & 2-High & China & Wuhan \\
\hline
\end{tabular}




\begin{tabular}{|c|c|c|c|c|}
\hline HDI Rank & HDI Value & Quartile & Country & Megacities \\
\hline 90 & 0.727 & 2-High & China & Shenyang \\
\hline 90 & 0.727 & 2-High & Taiwan & Taipei \\
\hline 93 & 0.726 & 2-High & Thailand & Bangkok \\
\hline 108 & 0.69 & 3-Medium & Egypt & Cairo \\
\hline 110 & 0.684 & 3-Medium & Indonesia & Jakarta \\
\hline 115 & 0.675 & 3-Medium & Philippines & Manila \\
\hline 116 & 0.666 & 3-Medium & South Africa & Johannesburg-Pretoria \\
\hline 116 & 0.666 & 3-Medium & Vietnam & Ho Chi Minh City \\
\hline 130 & 0.609 & 3-Medium & India & Delhi \\
\hline 130 & 0.609 & 3-Medium & India & Mumbai \\
\hline 130 & 0.609 & 3-Medium & India & Kolkata \\
\hline 130 & 0.609 & 3-Medium & India & Bangalore \\
\hline 130 & 0.609 & 3-Medium & India & Chennai \\
\hline 130 & 0.609 & 3-Medium & India & Hyderabad \\
\hline 142 & 0.57 & 3-Medium & Bangladesh & Dhaka \\
\hline 147 & 0.538 & 4-Low & Pakistan & Karachi \\
\hline 147 & 0.538 & 4-Low & Pakistan & Lahore \\
\hline 152 & 0.514 & 4-Low & Nigeria & Lagos \\
\hline 176 & 0.433 & 4-Low & DR Congo & Kinshasha \\
\hline
\end{tabular}

\section{How are Megacities Growing?}

In general, urban land cover - the amount of built-up area - has been increasing faster than urban population. The variance in settlement patterns contributes greatly to this. The global average density across all 45 megacities in this study is 963 people per square kilometer, a number that is highly skewed by the patterns of urbanization in the two nations with the greatest influence over urban planning worldwide, which are also the world's two largest economies - China and the United States.

For example, the urbanized area within the Shanghai municipality (not the megacity as this study has defined it) grew from 1,600 square kilometers to nearly 3,500 square kilometers from 2000 to 2010 , but its population density decreased from 8,700 to 6,900 people per square kilometer during the same period. This is despite the fact that Shanghai added 29 buildings of 200 meters or greater, and 115 tall buildings of all heights during the same period [6]. This pattern has been repeated across China - despite its urban population having increased by more than 130 million people between 2000 and 2010, average density has remained almost constant, at 5,300 people per square kilometer, with much construction occurring in places with declining populations [4].

The knowledge that urban land coverage significantly outpaces density in the US comes as less of a surprise. Its overall average is 110 people per square kilometer. America's densest metropolitan area, the New York-Philadelphia megacity as defined in this study, had an average of only 563 people per square kilometer. Having said this, as a new generation of Americans rejects suburban living for urban lifestyles (and workplaces follow suit), and as the aging baby-boomer population downsizes its dwellings and moves into downtowns and closer to amenities, the US is the only «highly developed» country that can expect a significant new wave of urbanization. It will add more than 100 million people to cities from 2010 to 2050 , increasing its urban population by $40 \%$ [4]. 
It is significant to note the development patterns that persist in the US and China, because these are the countries where most of the urban planning «prescriptions» for the rest of the world have thus far been devised. Also, much of the design, construction and economic power of the world is housed in, and deployed by, these countries. But both countries are outliers in terms of their spatial development, when compared to the rest of the world.

The US is well known for having devised a particularly expansive form of auto-centric urban sprawl. Long-distance commuting patterns have created far-flung suburbs in semirural settings, and as a result, have created expansive metropolitan areas recognized by the US Census Bureau. This is one reason why the study includes the urbanized area of southeastern Pennsylvania, all of New Jersey, and significant portions of southwest Connecticut in the «New York - Philadelphia» megacity, an area of 54,880 square kilometers. Even more dramatically, the «Los Angeles megacity» includes substantial areas of open desert between settlements within the Los Angeles - Long Beach, CA Combined Statistical Area (CSA), which encompasses 87,945 square kilometers - bigger than Austria and about the same size as Serbia.

China, «may also be an outlier, because its urban expansion has been accompanied by rapid economic growth, strong intervention by the central government in the urban expansion process, and massive investment in public infrastructure» [4]. In other words, most countries do not have characteristics that would easily yield a similar or appropriate response to their localized forms of urban growth.

\section{How Dense and Tall are Megacities?}

Of the 1,731 buildings measuring 200 meters or higher, that are currently completed or under construction worldwide, 958 , or $55 \%$ of these, are in the 45 megacities. Asia also claims the lion's share of 200-meter-plus buildings in megacities, with $774(81 \%)$ of the world's 958 (see Fig. 5). In addition to being the world's largest megacity by population, with nearly 65 million people, the Pearl River Delta also has the greatest number of buildings 200 -meters and taller - 220 - and the highest number of 200 -meter-plus tall buildings per capita - one for every 295,000 people. Nearly $30 \%$ of the 200 -meter-plus buildings in the world's megacities are here. But is it the densest?

Measured as a single entity, the answer is surprising. The Pearl River Delta contains some of the densest places in the world, in particular the Kowloon area of Hong Kong, which holds up to 32,100 people per square kilometer; but, overall, its vast 56,217-squarekilometer area has an average density of $1,154 \mathrm{~km} / \mathrm{m} 2$, ranking the megacity as the $23 \mathrm{rd}$ densest in this study (see Table 1). The twenty densest megacities are shown in Figure 6, with Karachi, Pakistan being the densest on average. Karachi has an average of 6,663 people for each of its 3,527 square kilometers - but only one building of 200 meters or taller (see Fig. 7). 


\section{$\%(\#)$ of $\mathbf{2 0 0} \mathrm{m}+$ Buildings \\ in Megacities by continent}

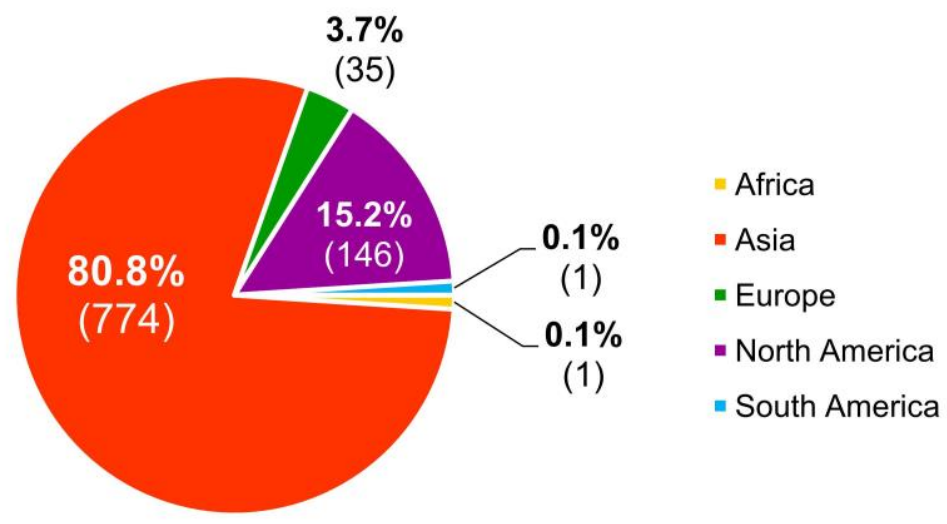

Fig. 5. Percentage and number of $200 \mathrm{~m}+$ buildings in megacities for each continent. (Source: CTBUH Skyscraper Center).

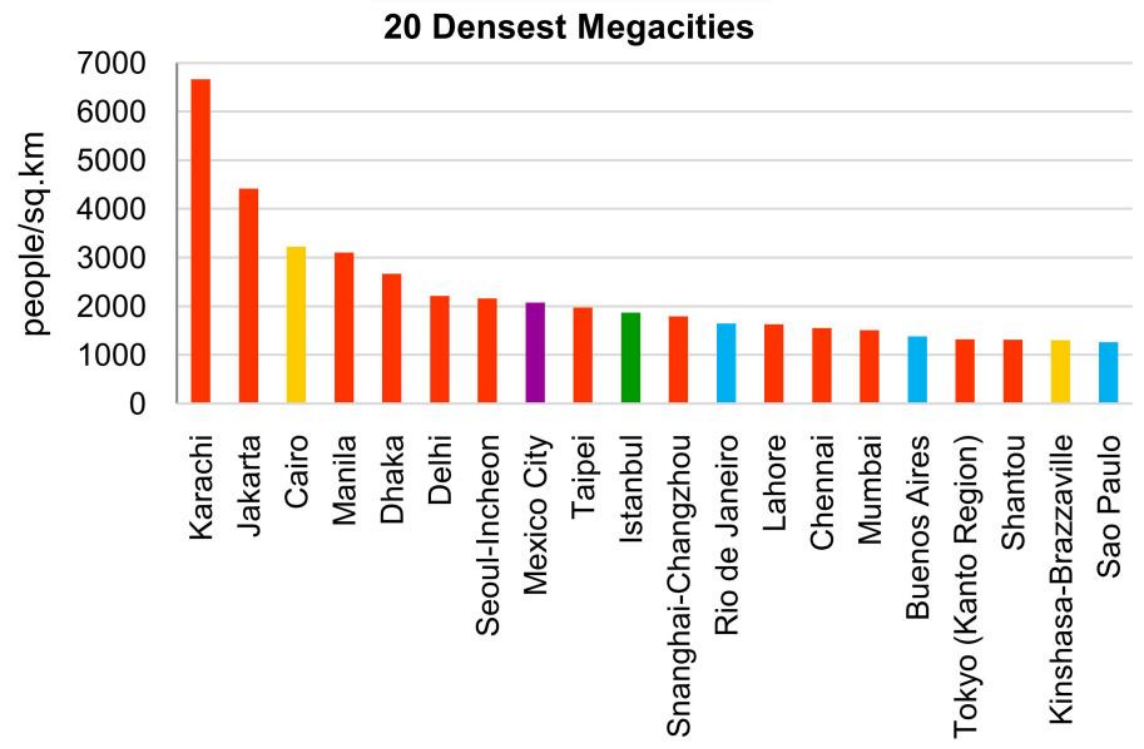

Fig. 6. Population density figures shown for the 20 densest megacities are derived from an averaging of density across the entire urban agglomeration. (Source: CTBUH and see «Population and Area Sources» in References).

Meanwhile, the vast informal settlements and transient populations of cities such as Mumbai and Dhaka make precise counts almost impossible, but it is generally accepted that these cities contain within them some of the most densely populated urban land on earth, in excess of 40,000 people per square kilometer in some places - and mostly in desperate urban conditions, in terms of space and infrastructure provisions. Even within this cohort low-lying cities on the Indian subcontinent - generalization is difficult. Mumbai is the world's 11th-biggest megacity in terms of population, and has 38 buildings of 200 meters or higher, while Dhaka is number 13, and has none (see Fig. 8, 9). 


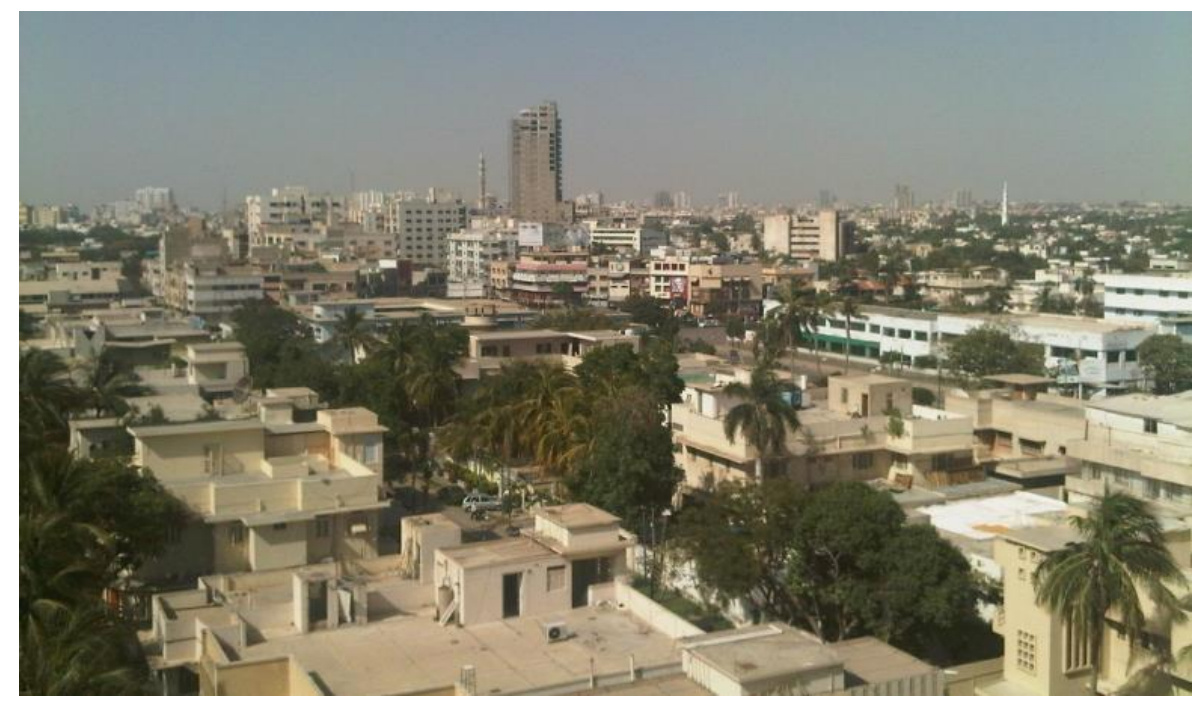

Fig. 7. Karachi’s cityscape. (Source: CC BY-SA Flickr account with username, «No Real Name»).
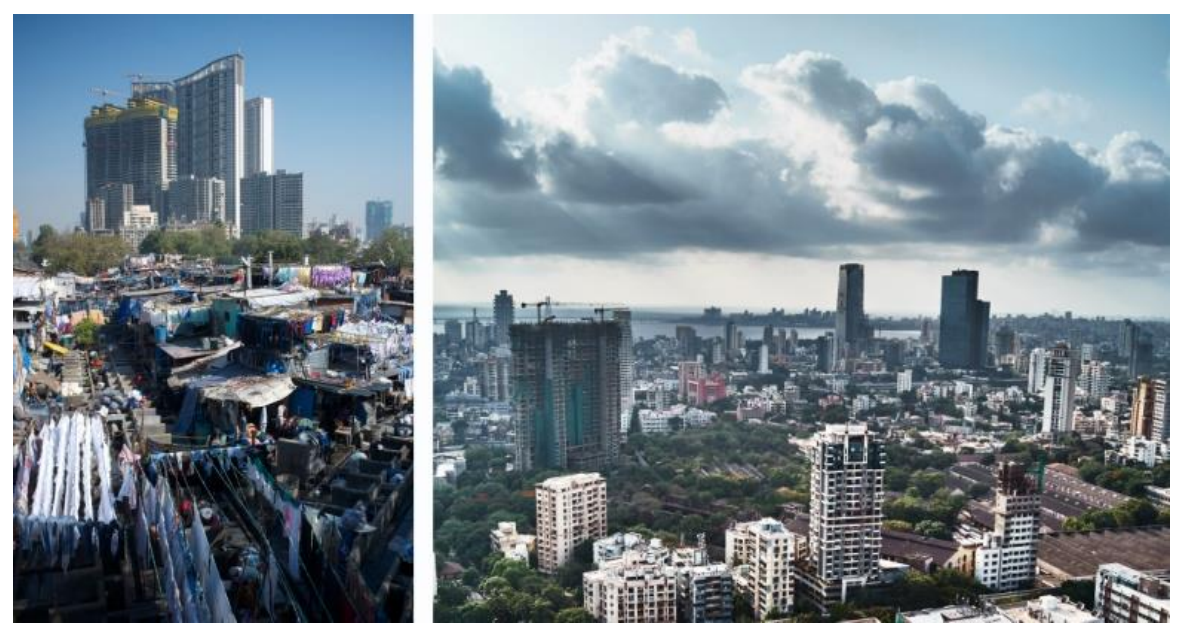

Fig. 8. (Left) New tall buildings rising above a laundry district in Mumbai and (Right) Mumbai cityscape. (Source: CC BY-SA Aleksandr Zykov and Vidur Malhotra).

In many ways, the Jakarta megacity is representative of the megacities still to come. By drawing a line around its urbanized area, from the Jakarta coastline to southern edge of Bogor, and from the Tangerang Regency boundary on the west to the Bekasi Regency boundary on the east, 28 million people fall within its orbit (see Fig. 10).

This makes Jakarta the ninth-largest megacity in this study in terms of population. Significantly, Jakarta has recently seen some of the most rapid tall-building construction outside of China. In 2015, the city saw seven buildings over 200 meters completed - the largest number of any city worldwide [6]. It also has a high population density, at 4,415 people per square kilometer (rank no. 2), and has forty-six 200-meter-plus buildings, ranking it no. 6 in this megacity survey. It's in a populous, economically-growing but still largely rural and poor country, with many low-lying areas susceptible to flooding. It is highly fragmented across multiple jurisdictions and travel corridors, and its infrastructure has not generally kept up with the speed of urbanization. 


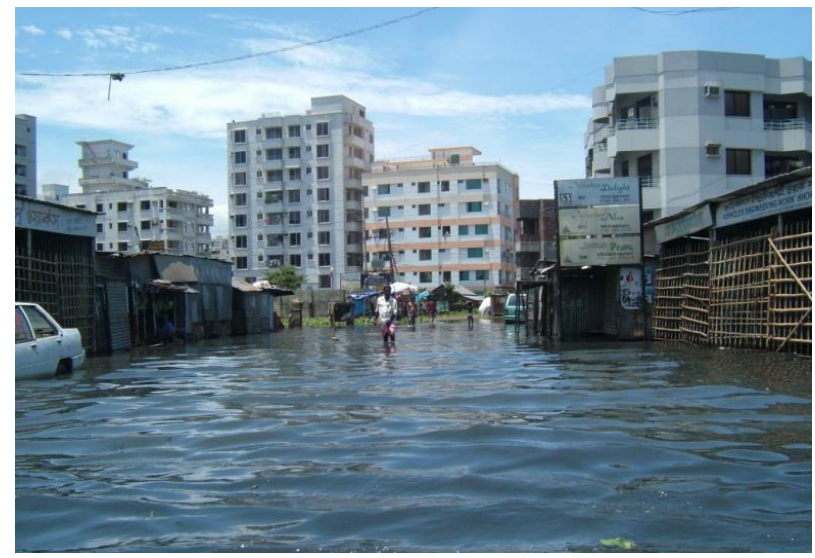

Fig. 9. 2004 flooding in the streets of Dhaka. (Source: CC BY-SA dougsyme).

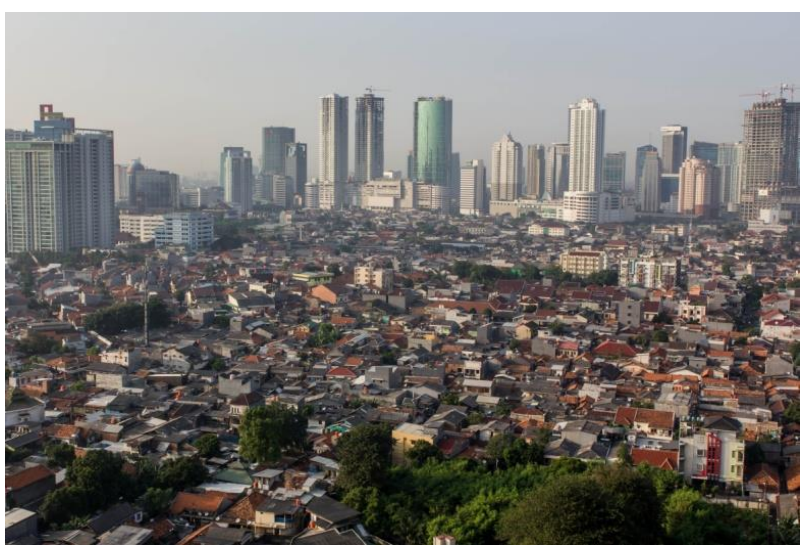

Fig. 10. Newer high-rise buildings juxtaposed with the traditional, low-rise urban context of Jakarta. (Source: CC BY-SA Magdalinski).

Cities like Jakarta, and those in less-developed conditions across South Asia and Africa, demonstrate both the enormous potential of, and the dire need for, heavy investments in transportation, infrastructure, and comprehensive regional planning. Without such improvements, the traditional, low-slung kampungs and the gleaming new towers alike will both be inundated by one or more vectors of a catastrophic combination: traffic, flooding, pollution, sewage, and social unrest. If they do not face total destruction, at the very least, large swaths of some megacities are at risk of becoming disconnected from the rest of the city and the world. Perhaps counterintuitively, some of the densest cities have the fewest tall buildings, and they tend to be comparatively under-developed economically and in terms of infrastructure. The majority of the world's poor are not living in tall buildings, but in low-rise, tightly packed dwellings with poor sanitation and building services. It is thus unsurprising that the default built «solution» to poverty for many cities, when the means become available, is to construct as many instances of a typology as close to the opposite of the sprawling shantytown as possible.

The result, to a large degree, has been the seemingly endless repetition of tall (though mostly sub-200-meter) modern apartment blocks, set in a «tower-in-the-park» model amidst broad roadways straight from Le Corbusier's visions. This model, devised for Europe in the 1920s but not implemented until after World War II, then repeated in America with public housing and Interstate highways in the 1950s and 1960s, and now in China, has gone 
virtually unchallenged for almost 100 years. Given the choice, of course, many of the urban poor would choose to live in dignity. But many believe the tower-in-the-park model isolates people and destroys the cultural integrity of their close-knit neighborhoods. The world clearly has much more densifying, vertical construction and poverty alleviation to do - the big question is, what shape will it take?

\section{Conclusions}

Megacities comprise $13.1 \%$ of global population and occupy $0.66 \%$ of its land surface area. From this, it would be logical to infer that megacities demonstrate a high degree of sustainability with respect to land use. But their energy use, their disproportionate location along coastlines and deltas, and their population growth rates will have much wider implications than their built-up surface areas would suggest.

Even if megacities do not yet contain anything near a majority of the world's population, their strategic importance to national and global economies is difficult to overstate. The Shanghai and Pearl River Delta clusters account for less than $25 \%$ of China's population, but account for $80 \%$ of its exports [5]. The implications of having to «move» even one of these megacities inland, or undertake massive coastal defense works, or elevate the ground plane to safety beyond new flood zones, are mind-boggling - but that is not an excuse for not thinking about the possibility. What happens in megacities matters disproportionately to the rest of the world, which is well on its way to becoming $70 \%$ urban. Any interventions of design, planning, construction or governance in these cities will not only affect a great number of people in the first instance, but their effects will be amplified across the world due to the disproportionate significance of these cities as economic engines. The world is becoming an increasingly interdependent place. As we know only too well from revelations about greenhouse gases, climate change and the rapid spread of viruses - both biological and technological - the choices we make in one part of the world are likely to affect many others. Nowhere is this more the case than when discussing pieces of critical infrastructure set in the world's megacities. There will not be one «template» that can be copied around the world to solve all of its problems, but that does not mean we should not think «big». This is a community that has no difficulty thinking big. The «big thinking», however, needs to extend beyond the height and style of individual buildings, and to instead think in terms of systems - tall buildings need to become part of a three-dimensional, globally-connected, and locally-vital, infrastructure. Tall buildings are critical infrastructure, not just users of it. Those who finance, design and operate them, and decide where they should be built, need to think of them this way, if they are truly to be part of the solution.

\section{References}

1. http://www.nationsonline.org/oneworld/countries_by_area.htm, last accessed 2017/08/25

2. S. J. Angel, Planet of Cities Cambridge (MA: Lincoln Institute of Land Policy 2012)

3. http://hdr.undp.org/sites/default/files/hdr_2015_statistical_annex.pdf, last accessed 2017/08/25

4. www.worldbank.org/eap/MeasuringUrbanExpansion, last accessed 2017/08/25

5. P. Khanna, Connectography (New York: Random House, 2016)

6. www.theskyscrapercenter.com, last accessed 2017/08/25. 
7. http://www.lincolninst.edu/subcenters/atlas-urban-expansion/, last accessed 2017/08/25.

8. http://www.mckinsey.com/industries/infrastructure/our-insights/the-power-ofcollective-action-forging-a-global-role-for-mayors?cid=other-eml-alt-mip-mck-oth1606, last accessed 2017/08/25.

9. R. Florida, T. Gulden, C. Mellander, The Rise of the Mega-Region (Cambridge Journal of Regions, Economy and Society 2008) 1 Issue 3, 459-476 pp

10. www.hsbc.com/ /media/hsbc-com/investorrelationsassets/.../prd-factbook, last accessed 2017/08/25.

11. http://china-trade-research.hktdc.com/business-news/article/Fast-Facts/PRDEconomic-Profile/ff/en/1/1X000000/1X06BW84.htm, last accessed 2017/08/25.

12. http://data.worldbank.org, last accessed 2017/08/25. 